\begin{tabular}{lc}
$\mathbf{V}$ & $\mathbf{R}$ \\
\hline & $\substack{\text { ROCZNIKI HUMANISTYCZNE } \\
\text { Tom LXVII, zeszyt } 7-2019}$ \\
DOI: http://dx.doi.org/10.18290/rh.2019.67.7-10
\end{tabular}

ЛЮДМИЛА СІРИК

\title{
ПРОБЛЕМА ІДЕНТИФІКАЦІЇ ТВОРЧОСТІ ЛЕСІ УКРАЇНКИ
}

Дискусійним в українському літературознавстві залишається питання щодо ідентифікації з певним мистецько-художнім напрямом творчості Лесі Українки (1871-1913) - класика української літератури, перекладача-поліглота, інтелектуала і особистості широких європейських горизонтів. Домінує погляд і склалася традиція під впливом народницької критики ідентифікувати письменницю 3 неоромантизмом. Наголос ставиться передовсім на поезії громадянського звучання, зокрема національно-визвольного характеру і на драмі-фейєрії Лісова пісня (1911), яка проникнута українським фольклором і волинсько-поліською міфологією, проблемами і прагненнями українського селянства. Великий розголос мала присвячена національно-визвольній тематиці драма Бояриня (1913), яка стала доступною для широкого загалу читачів аж після розпаду радянської імперії. Тимчасом замовчується або усувається в тінь погляд, який вказує на винесені з класичної традиції світоглядні та мистецькі пріоритети і дає підстави зараховувати письменницю до неокласицизму. Менш освоєними в читацькій свідомості і науково осмисленими є іiі класичні драми, зокрема Одержима, Кассандра, Руфін і Присиілла, Камінний госnодар, в яких творчо і з проекцією на українську дійсність вико-

Dr hab. LUDMIŁA SIRYK - adiunkt Zakładu Filologii Ukraińskiej w Instytucie Filologii Słowiańskiej UMCS; e-mail: 1.siryk@ poczta.umcs.lublin.pl 
ристано „вічні” образи й сюжети античності та християнства, а також піднято загальнолюдські проблеми.

У зв'язку з існуючою дилемою, пропонована стаття є спробою показати погляди на тему ідентифікації Лесиної творчості двох опозиційних точок зору. Об'єктом дослідження є літературознавчі праці Сергія Єфремова, Дмитра Донцова і київських неокласиків, а також листи Лесі Українки. Автор статті висуває тезу про приналежність письменниці до неокласицизму - одного з напрямів європейського модернізму, в річищі якого вона перебувала на зламі XIX-XX століть. Метою дослідження є також спроба підкреслити необхідність сьогодні мериторичної дискусії щодо існуючої проблеми, оскільки письменниця вже за свого життя не погоджувалася з оцінкою і мистецькою ідентифікацією своєї творчості. У працях відомих сучасних літературознавців творчість письменниці осмислюється в контексті явища модернізму ${ }^{1}$ (Т. Гундорова, С. Павличко, М. Моклиця, Я. Поліщук та ін.), однак згадане щойно питання не порушується.

На наш погляд, тенденцію зараховувати Лесю Українку до неоромантизму започаткували і мали великий вплив на ії становлення Єфремов і Донцов, котрі в українському середовищі мали авторитет як літературні критики і суспільно-політичні діячі. У прочитанні літературних явищ вони застосували соціологічний критерій, свідченням чого є, зокрема, стаття Донцова Поетка українського рісорджименто (Леся Українка) ${ }^{2}$ і присвячений Лесі Українці підрозділ у монографії Єфремова Iсторія украйнського письменства ${ }^{3}$. Остання за життя автора мала чотири видання (перше 1911 р., останнє 1929 р.), а п'яте з'явилося в 1995 зі вступною статтею про Єфремова ${ }^{4}$. Тепер названі публікації функціонують в Інтернеті $^{5}$ як у формі оригінальних текстів, так і за посередництвом рефератів чи більших наукових праць.

\footnotetext{
${ }^{1}$ Напр. „У фундаментальних дослідженнях останніх років про творчість Лесі Українки та Ольги Кобилянської робиться послідовний наголос на модернізмі” (М. Моклиця, Естетика Лесі Украйнки (контекст європейського модернізму), Луцьк: ВНУ ім. Лесі Українки 2011, с. 192).

2 Д Донцов, Поетка українського рісорджименто (Леся Українка), [в:] Украӥнське слово: Хрестоматія української літератури та літературної критики XX cm., у чотирьох книгах, кн. I, Київ: Рось 1994, с. 140-183. Далі цитую статтю за цим виданням, номер сторінки вказую в тексті - Л. С.

${ }^{3}$ С. СФремов, Історія украӥнського письменства, Київ: Femina 1995. Далі цитую за цим виданням, номер сторінки вказую в тексті - Л. С.

${ }^{4}$ Див. М. НАєнко, Сергій Сфремов і його історико-літературна кониепиія, [в:] С. ЄФРЕмов, Історія украӥнського письменства с. 3-15.

${ }^{5}$ Див., напр. http://www.ukrcenter.com/!FilesRepository/Literature\ [від: 21.11.2017].
} 
У твердженні Єфремова прочитується нечіткість характеристики Лесиної творчості та вжито термін неоромантичний

\footnotetext{
Леся Українка стоїть ніби в центрі нашої новішої поезії, з одного боку торкаючись попереднього гурту письменників, у яких голосніше бринить громадянська струна; 3 другого - сама дає почин тій індивідуалістичній, на неоромантичній [виділено мною - Л.С.] основі, поезії, що останніми часами все дужче починає у нас озиватись [с. 524].
}

Також у статті Донцова Поетка украӥнського рісорджименто..., вперше опублікованій 1922 року в „Літературно-Науковому Віснику” (ч. V), надано примат таким категоріям як воля, відвага, завзяття [c. 150], націоналізм [c. 151] і нація [с. 182-183]. Вказуючи на прометеїзм і волюнтаризм Лесі Українки, критик вбачає в ній ідеолога національно-визвольного руху та відродження. Разом із тим він сам собі суперечить, вважаючи індивідуалізм письменниці „скрайнім” і „розпачливим”. В аналізі творчості критик зосередився тільки на суспільно-політичному аспекті. Тимчасом проблеми універсального характеру, зокрема онтологічні, етичні й антропологічні, лишилися поза його увагою. Проте риторика Донцова подобалася українському суспільству: в літературознавстві та читацькій свідомості прижилися окреслення „поетка українського рісорджименто” і „дочка Прометея”, вжиті з метою уславлення героїки романтизму і пропагування національної ідеї.

Прикметно, в щойно згаданій монографії Єфремова авторці Кассандри відведено дуже мало місця, неповні 4 сторінки [с. 524-528]. Цьому короткому огляду характерно кілька ознак. По-перше, міркування критика спираються лише на поезії початкового періоду творчості письменниці, ïx заміщено в XIII розділі, присвяченому українській літературі 80. років XIX століття. По-друге, розділ XIV під назвою „Дев'яності роки” містить такі підрозділи як: а) Кобилянська; б) Яцків і модерністи; в) Стефаник і його школа; д) На світанні. Тут Лесю Українку згадано лише принагідно, хоч вона на зламі XIX-XX ст. свідомо й активно включилося в європейський модернізм. По-третє, зараховуючи письменницю до „поетів-демократів", критик аналізує передовсім твори зі збірки початкового періоду Думи $i$ мрії (1899), зокрема вірші громадянського звучання

\footnotetext{
${ }^{6}$ Рісорджименто (італ. il risorgimento - відродження, оновлення) - термін, який означає національно-визвольний рух італійського народу проти іноземного гноблення, за об’єднання Італії в одну державу та досягнення політичної незалежності (XIX ст.).
} 
Горить моє серие... (1894), До товаришів (1895), Поет під час облоги (1896), Товаришці на спомин (1896), Хвилина розпачу (1896), Fiat nox! (1896), Слово, чому ти не твердая криия... (1896), Порвалася нескінчена розмова... (1898), Де поділися ви, голоснії слова... (1900), та позитивно оцінює їх ідеологічне спрямування в національному вимірі. Натомість поза його увагою лишаються антропологічні проблеми і гуманістичні ідеї творчості - $є$ лише коротке твердження, що поетеса „вміла просто зачепити натхненною піснею щоденні струни в душі людській” [с. 525]. Почетверте, Єфремов легковажить драматургію письменниці, психологічну п'єсу Блакитна троянда (1896) і створені з використанням символіки образів і сюжетів античності та християнства драматичні поеми і соціально-філософські драми Одержима (1901), Осіння казка (1905), В катакомбах (1905), Кассандра (1907), У пущі (1909), Йоганна, жінка Хусова (1909), Руфін і Прісиіла (1911), Адвокат Мартіан (1911), Лісова пісня (1911), Камінний господар (1912), Оргія (1913). Леся Українка як ніхто інший в українській літературі того часу виявила новаторство в драматургії. Однак Єфремов не аналізує жодного твору, обмежуючись лише переліком назв і короткими інформаціями до деяких з них. Таким чином, творчість дозрілого періоду критик трактує як факт маргінальний. В його твердженнях простежується суперечливість: то в Лесі Українці він вбачає „занадто сучасну людину”, а то письменника „з розчахнутою душею”; то твердить про її дистанцію від життя (,абстрагування образів од сучасної дійсності”), а то посилено наголошує їі демократичність („справжній «поет під час облоги» [...] вміла дошкулити ворога своїм дужим словом, вдихнути бадьорість і волю до активності й діла") [с. 525]). Крім того використання „вічних образів і сюжетів”, зачерпнутих з європейської класики, Єфремов вважає відходом від національних інтересів, а в філософській та інтимній ліриці вбачає декадентські риси. В одному з його тверджень прочитується розчарування:

Потроху й у неї самої, в її творчості, одбувається виразний перелом: дедалі все ти хше бринить отой міцний і дужий поети-громадянина, і Леся Українка все частіше тікає вглиб віків, немов, щоб там знайти пристановище та захисток од гіркої дійсності й ослабити почуття власної самотності. I раніш охоча до екскурсів у давню старовину, в світ романтичних подій та настроїв, в останні роки свого життя поетеса майже не виходила 3 нього [с. 526-527].

Не можна погодитись $з$ його поглядом, що алюзії до давнини суперечать громадянському духові національної поезії, що драми Оргія, Руфін i Прісиіла, Кассандра не порушують актуальних на той час суспільно-по- 
літичних питань і що вони менш важливі, ніж цитовані критиком Невільничі nicнi. Про негативне ставлення Єфремова до творчої методології драматурга свідчить також факт, що в збірці Думи $і$ мрії поза аналізом лишаються поеми на стародавні сюжети Роберт Брюс і Давня казка. Тимчасом, у цих творах через призму минулого, яке проектуються на українську дійсність, піднято кардинальні громадянські проблеми, ідея боротьби за свободу й за гідність людини і народу. На наш погляд, сповідуючи ідеологію народництва, критик насилу „втиснув” письменницю в неоромантизм, де надається примат категорії народності.

Як бачимо, Сфремов і Донцов розглядали Лесину творчість вибірково, аналізували і популяризували лише поезію громадянського звучання. Обидва критики зосередились на ролі творчості в формуванні національної свідомості та в поширенні патріотично-демократичних ідей. Надаючи примат соціологічному принципу в оцінюванні мистецьких явищ, вони керувалися ідеологічним критерієм. Останній зумовлює утилітарне трактування літератури, наголошення іiї прагматичної функції, тенденційність характеристики. Такий підхід спричиняє неадекватну ідентифікацію письменниці щодо ії̈ приналежності до мистецько-художнього напряму.

Предмет дослідження вимагає, щоб сягнути до поглядів самої Лесі Українки. Ї̈̈ листи до близьких свідчать про конфлікт письменниці 3 критиком. „Єфремов зачепив мене, як критика і як публіциста, то мені мовчати не випадає”, - писала вона в листі до Ольги Кобилянської 10 січня 1903 року. В іншому з листів вона не тільки нарікає на неадекватну характеристику, а виражає обурення:

Зайнята була, між іншим, полемікою проти статті Єфремова в „Київській старині”, де він зачисляє мене до „вредных антиобщественных” елементів за те, що я, нібито, тягну руку за декадентів і символістів. Я пояснюю, що декаденти і символісти мене нічого не обходять, окреслюю деякі риси мого напряму [виділення моє - Л.С.] і запрошую п. Єфремова „выражаться точнее и разборчивее”. Інакше буде кепсько для його „литературного флага”. Стаття Єфремова написана прекапосним тоном і дуже мене обурила не так за мене (я там приплетена «між іншим»), як за Кобилянську (вона ж там найвреднішою виходить) і взагалі за правду. Обзивається давня Конищина

\footnotetext{
${ }^{7}$ О. КОСАЧ-КРИВинЮК, Леся Українка. Хронологія життя і творчості, Луцьк: Волинська обласна друкарня 2006, с. 660.
} 
і нудить мене від неї і поривається в мені душа нащадка Драгоманова. Певне Єфремов зачепить мене ще раз, не думаю, щоб він „з’їв і облизався”, ну тим гірше буде для нього, бо я вже вдруге вдарю „нещадно”, а тепер ще, тим часом, „церемонюся” „рыцарство”, „бачте обуяло” (з листа від 14 січня 1903 р. до М. В. Кривинюка) ${ }^{8}$.

На наш погляд, виділений курсивом фрагмент „риси мого напряму” може бути пунктом виходу до вивчення естетико-світоглядних і художньостильових ознак мистецької програми і самоідентифікації Лесі Українки. Критика нею оцінок Єфремова дають підставу твердити про хибність поглядів народницької платформи щодо ідентифікації творчості письменниці 3 неоромантизмом.

Погляд, який дозволяє ідентифікувати Лесю Українку з неокласицизмом, висловили у двадцятих роках XX ст. чільні представники літературного угруповання київських неокласиків Микола Зеров, Михайло ДрайХмара, Павло Филипович, Максим Рильський, Юрій Клен (спр. Освальд Бурггардт) - літературознавці, критики, історики і теоретики літератури. В цьому погляді утверджують нас деякі сучасні українські та польські посібники, в яких Лесину драматургію ідентифіковано 3 неокласицизмом ${ }^{9}$.

Київські неокласики не вживали терміну неокласицизм, але аргументовано довели класичність творчості та європеїзм письменниці. Проте погляди неокласиків, висловлені у 1920. роках а потім лише Рильським і Юрієм Кленом, яким пощастило врятуватися під час сталінського терору та II світової війни, не мали умов на поширення. Протягом 1930 1990 років їхня наукова думка була заборонена радянською цензурою і стала доступною для читацького загалу аж в умовах суверенної України. Вперше предметом дослідження поглядів неокласиків на творчість Лесі Українки стала в 1991 році праця Марії Зубрицької ${ }^{10}$, але там проаналізо-

\footnotetext{
${ }^{8}$ Там само, с. 661 .

9 Див. Лексикон загального та порівняльного літературознавства, Чернівці: Золоті литаври 2001, с. 369; W. WILCZYŃSKI, Leksykon kultury ukraińskiej, Kraków: Universitas 2004 , c. 158

${ }^{10}$ М. ЗуБрицкАЯ, Творчество Леси Украинки в оченке «неоклассиков». Автореферат диссертации на соискание учёной степени кандидата филологических наук, Киев 1991.
} 
вано думку неокласиків про поетику художньої уяви поетеси, однак підняте нами питання не порушено.

Зібрання праць неокласиків на тему Лесі Українки може становити два солідні томи. Протягом 1926-1929 років М. Драй-Хмара опублікував монографію Леся Українка. Життя і творчість і статті: Поема Лесі Українки „Вілла-посестра” на тлі сербського та украйнського епосу, Бояриня ${ }^{11}$, Іван Франко і Леся Українка (3 полеміки 90-х років) ${ }^{12}$. В доробку М. Зерова є низка статей ${ }^{13}$, а саме: Леся Украйнка (3 нагоди нового видання творів) (1919), Леся Украӥнка. Критично-біографічний нарис (1924), Листи Лесі Украӥнки до Михайла Кочюбинського (1924), 3 листування Лесі Украӥнки (1925), Леся Украӥнка і читач (3 нагоди п'ятнадиятих роковин з дня смерті) (1928), Леся Українка та ї̈ „Лісова пісня” (1929), Руфін і Прісцілла (До історії задуму і виконання) (1930) [спочатку була передмовою т. VII 12-титомника поетеси, у підготовці якого вчений брав участь], та три рецензії, а саме: на біографічно-критичну монографію А. Музички Леся Українка (Одеса 1925), Леся Українка. „В катакомбах” і інші п'єси (1920) і Леся Украйнка. Поеми [рік видання не вказано]. В доробку Филиповича є три статті, тобто дві однойменні Леся Украӥнка ${ }^{14}$ і Образ Прометея в творах Лесі Украӥнки ${ }^{15}$. У 1927 році Юрій Клен (тоді ще Освальд Бурггардта) опублікував статтю Леся Українка $і$ Гайне $e^{16}$, а на еміграції в університеті міста Інсбрук читав німецькою мовою спецкурс „Леся Українка та їі переклади з Генріха Гайне"17. В період 40-60-х pp. ХX ст. Рильський опублікував статті українською мовою, тобто Лірика Лесі Українки, Співець свободи і братерства народів - Леся Украӥнка (До 75-річчя з дня народження), Промова на вечорі з нагоди 40-ї річниці від дня смерті Лесі Українки, [Промова на конференції, присвяченій 50-річчю від дня смерті Лесі Українки], Слово про Лесю Українку,

\footnotetext{
${ }^{11}$ Ця публікація була вступною статтею до Лесиної поеми Бояриня у зібраному виданні Леся Українка, Твори, т. VIII, Київ: „Книгоспілка” 1929, с. 87-109.

${ }^{12}$ Названі праці див. М. ДРАй-ХмАРА, Літературно-наукова спадщина, Київ: Наукова думка 2002.

${ }^{13}$ М. ЗЕРОв, Українське письменство, упор. М. Сулима, Київ: Основи 2003.

${ }^{14}$ Одна стаття вперше була надрукована як передмова до збірки поетеси Поеми (Київ 1920), а друга - це невеличка ювілейна стаття („Нова громада” 1923, № 7-8).

${ }^{15}$ Названі статті див. П. Филипович, Літературно-критичні статті, Київ: Дніпро 1991.

${ }^{16}$ Див. О. БУРІГАРДт, Леся Украйнка і Гайне, [в:] Л. УКРАїнКА, Твори. Переклади, т. IV, Київ 1927, с. VII-XXIV).

${ }^{17}$ Інформацію подаю за: Ю. КовАлІв, Прокляті роки Юрія Клена, [в:] Ю. КлЕН [О. БУРГАРдт], Вибране, Київ 1991, с. 14.
} 
а також статті російськомовні: Леся Украинка ${ }^{18}$, О переводе «Каменного хозяина» Леси Украинки, выполненного Н. Ушаковым, Вдохновенное слово. Произведения Леси Украинки на русском языке ${ }^{19}$.

Мистецько-громадянську позицію письменниці неокласики вважали зразком до наслідування, бо вона „підіймала українське письменство до рівня європейського" Українки „є дуже мало спільного зі світоглядом українського інтелігентського народництва" 21 . Предметом осмислення неокласиків є естетикосвітоглядні пріоритети, стильові риси і методологія творчості. Критики вказують на низку ознак іiі творчої стратегії, а саме:

1. Звернення до стародавності, творче використання „мандрівних сюжетів” й „вічних образів” античності та християнства. Одним із чітких свідчень $є$ Лесин вірш початкового періоду творчості Contra spem spero (1890). В монографії Леся Українка. Життя і творчість ${ }^{22}$ Драй-Хмари читаємо, що вона „почувала себе людиною європейської, а тим самим і греко-римської культури" [с. 62]. Всупереч народницькій критиці неокласики пояснюють суть і символіку елементів т.зв. „екзотизму” і „архаїзу” іiі творчості:

Леся Українка вибрала шлях, яким ішли Данте та Гете, що шукали великих пристрастей у минулому. Їх знаходить Леся у стародавніх євреїв, у греків та римлян часів занепаду, у первісних християн, у героїв Великої французької революції і хоче ці пристрасті, цей огонь бунтівливих душ перелити в оспалі серця своїх сучасників [М. Д.-Х.: Л. У., 116-117].

[До речі, сама письменниця констатувала, що „екзотизм” і „космополітизм" не суперечить національним інтересам і орієнтаціям $]^{23}$. Критики

\footnotetext{
${ }^{18}$ М. Рильський, Зібрання творів у двадияти томах, т. ХІІ, Київ: Наукова думка 1986.

${ }^{19}$ М. Рыльський, Искусство перевода. Статьи, заметки, письма, Москва 1986.

${ }^{20}$ П. Филипович, Леся Українка, [в:] той САмий, Літературно-критичні статті..., c. 107. Далі ініціали автора „П. Ф.”, назву статті, записану „Л. У.” і номер сторінки вказую в тексті - Л. С.

${ }^{21}$ М. ЗЕРОВ, Леся Украӥнка. Критично-біографічний нарис, [в:] той САмИй, Українське письменство..., с. 411. Тут і далі подаю за вказаним збірником Зерова інші статті, вказуючи сторінку; натомість в іншому випадку подаю бібліографію використаного джерела - Л. С.

${ }^{22}$ М. ДРАЙ-ХмАРА, Леся Украӥнка. Життя і творчість, [в:] тОЙ САМИЙ, Літературно-наукова спадщина..., с. 35-151. Далі ініціали автора „М. Д-Х.”, назву праці, записану „Л. У.” і номер сторінки вказую в тексті - Л. С.

${ }^{23}$ Див. Л. УКРАИНКА, Заметки о новейшей польской литературе, [в:] ТА САМА, Твори в десяти томах, т. VIII, Київ: Дніпро 1965, с. 106-133.
} 
3'ясовують аксіологію та контекстуальну функцію „вічних” сюжетів і образів, символіку яких драматург творчо накладала на сучасну ій українську дійсність.

2. Творче наслідування кращих світових зразків і реалізація гасла „До джерел”. Рильський помічає яскраві „сліди навчання в античних трагіків, у Пушкіна, Лермонтова, Некрасова, Міцкевича, а також у Гейне "24 і досконалість художньої форми („Мальовничість, пластичність іiі образів мало має собі рівних у світовій літературі" $\left.{ }^{25}\right)$. Зеров підносить 甪 на рівень літературного Парнасу:

[...] класичність Лесі Українки трохи й охолоджує враження; останню сторінку їі драми перегортаєш з тим самим почуттям, яке викликає шекспірівська трагедія: думка й почуття однаково зворушені ${ }^{26}$.

3. Орієнтація на високі духовні прагнення людини та дистанція від буденщини як згубного фактору (,в Лісовій nicнi змальовано трагедію людської душі, що заблудилась серед болота буденного людського життя" [М. Д.-Х.: Л. У., 145]. Поетеса „високо підносилась над життьовими обставинами, абстрагувалася від них" [М. 3.: Р. і П., 871].

4. Антропоцентризм 3 етичним підтекстом. За спостереженням Рильського, „жадібні очі поетеси скрізь бачили насамперед - людей [...] вона читала їх думки, проймалася їх настроями",27.

5. Реалізація засади громадянської активності, піднесення сили духу. Згідно з неокласиками, письменниця „сформувала світогляд під впливом західноєвропейських філософів і митців європейської індивідуалістичної думки, від [...] Байрона до Ібсена та Ніцше" ${ }^{28}$, але іiі індивідуалізм не скрайній, а поєднаний зі „стихійним демократизмом” [М. Д.-Х, Л. У., 141], „творчий і конструктивний” [Л. У., 107], насичений соціальним змістом та протестом проти невільницького духу, кволості й пасивності громадянства. Поетеса не відгороджується від дійсності, не утворює культу свого „я”, а „хоче розворушити темні і пасивні маси до боротьби за визволення" [П. Ф.: Л. У., с. 107]. До речі, Леся Українка 1903 року пи-

\footnotetext{
${ }^{24}$ М. Рильський, Лірика Лесі Украӥнки, [в:] той САмий, Зібрання творів..., с. 162.

${ }^{25}$ Там само, с. 164.

${ }^{26}$ М. ЗЕРОв, Руфін і Прісиілла (До історії задуму $і$ виконання), [в:] той САмий, Українське письменство..., с. 869. Л. С.: Цитуючи цю статтю далі, ініціали автора „М. 3.” і назву статті скорочено „Р. $і$ П. ” подаю в тексті.

${ }^{27}$ М. Рильський, Лірика Лесі Украӥнки..., с. 159.

${ }^{28}$ М. ЗЕРОв, Леся Украӥнка. Критично-біографічний нарис..., с. 410.
} 
сала: „Нехай мій голос буде просто «голосом з народу» - на більше значення я не важу" 29.

6. Методологія творчості (,письменниця орудує в своїх драмах дедуктивним методом [...] загальноприйнятим методом серед елітного письменства в Європі”- М. Д.-Х.: Л. У., 119), яка зумовила новаторство:

українські поети відчули „весь жах старого українського сентименталізму в ліриці, того штучного і присолодженого стилю, що став ніби обов'язковим [...] одні прагнули нового і не мали сили до нього добитися; другі мало говорили про нові напрямки, а проте у своїй поезії справді принесла нову дійсність, новий стиль Леся Українка"

В iï творчій манері критики вбачали символізм мислення, аналітичность, поєднання універсального і національного, творче використання джерел європейської класики, примат еллінського ідеалу краси та ідей Ренесансу і Просвітництва, стильовий синкретизм. Підкреслили значення адаптації класичної традиції на грунті української національної літератури:

Так міцно стоячи на європейському грунті, Леся Українка могла сміливо розвинути вузькі межі українського тогочасного письменства, яке лише починало відходити од етнографізму, переспівування Шевченка та російських громадянських співців 80-х років [П., Ф.: Л. У., с. 106]

Неокласики, керуючись естетичним критерієм в оцінці мистецько-художніх явищ ${ }^{31}$, вказують на риси, характерні для класицистичного типу творчості. У світлі студій неокласиків письменниця, не будучи формально причетною до неокласицизму, фактично реалізувала його мистецько-художні положення ${ }^{32}$.

\footnotetext{
29 Л. УКРАїнКА, Замітки з приводу статті „Політика і етика”, [в:] ТА САМА, Твори в десяти томах, т. VIII, с. 234-248.

${ }^{30}$ М. ЗЕРОв, Передмова до збірника „Нова украӥнська поезія”..., с. 324.

31 ”Н. Зеров ставит произведения Леси Украинки в зависимости от подлинно эстетических факторов“ (М. ЗУБРицКАЯ, Творчество Леси Украинки..., с. 2).

${ }^{32}$ Про теорію неокласицизму див. Л. СІрик, Прагнення Європи. Творчість київських неокласиків, Lublin: Wydawnictwo Uniwersytetu Marii Curie-Skłodowskiej 2013.
} 
Представлені погляди щодо ідентифікації Лесиної творчості в плані мистецько-художного напряму дозволяють вважати думку народницької критики хибною і схилятися до думки неокласиків. Головною причиною антиномії в ідентифікації є різні підходи в оцінці творчості: застосування соціологічного й ідеологічного критерію зумовлює ідентифікацію письменниці 3 неоромантизмом, натомість примат естетичного критерію - 3 неокласицизмом. Причиною дилеми є також Лесина творчість, яка має синкретичний характер, єднає в собі досвід різних мистецьких напрямів і культурних традицій. Думається, проблему розв'яже застосування відповідного теоретико-методологічного інструментарію в аналізі творчості й наукової думки письменниці, українського класика європейського рівня.

\section{БІБЛІОГРАФІЯ}

Бурггардт, О. „Леся Українка і Гайне”. Леся Українка. Твори. Т. 4. Переклади. Київ, 1927. VII-XXIV [Burghardt, O. „Lesia Ukrainka i Heine”. Lesia Ukrainka. Twory. T. 4. Pereklady. Kyjiv, 1927. VII-XXIV].

Гундорова, Т. ПроЯвлення Слова. Дискурсія раннього українського модернізму. Київ: Часопис «Критика», 2009 [Hundorowa, T. ProJavlennia Slowa. Dyskurs rannioho ukrajins'koho modernizmu. Kyjiv: časopys „Krytyka”, 2009].

Донцов, Д. „Поетка українського рісорджименто (Леся Українка)”. Українське слово: хрестоматія української літератури та літературної критики XX століття. У чотирьох книгах. Кн. 1. Київ: Рось, 1994. 140-183 [Doncow, D. „Poetka ukrajins'koho risordžymento (Lesia Ukrainka)". Ukrajins'ke slowo: chrestomatia ukrajins'koji literatury ta literaturnoji krytyky XX stolitt'ia. U čotyrioch knyhach. Kn. 1. Kyjiv: Ros', s. 140-183].

Драй-Хмара, М. Літературно-наукова спадщина. Київ: Наукова думка, 2002 [Draj-Chmara, M. Literaturno-naukova spadščyna. Kyjiv: Naukowa dumka, 2002].

Єфремов, С. Історія українського письменства. Київ: Femina, 1995 [Jefremow, S. Istorija ukrajins'koho pys'menstva. Kyjiv: Femina, 1995].

Зеров, М. Українське письменство. Упор. Мукола Сулима. Київ: Основи, 2003 [Zerow, M. Ukrajins'ke pys'menstvo. Upor. Mykoła Sulyma. Kyjiv: Osnovy, 2003].

Зубрицкая, М. Творчество Леси Украинки в оценке „неоклассиков”. Автореферат диссертации на соискание учёной степени кандидата филологических наук. Киев: АН УССР. Институт литературы им. Тараса Шевченко, 1991 [Zubrickaja M. Tworčestvo Lesi Ukrainki w ocenkie „neoklassikov”. Avtoriefierat dissiertacii na soiskanije učionoj stiepieni kandidata filologičeskich nauk. Kijev: AN USSR. Institut literatury imeni Tarasa Ševčenko, 1991]. 
Ковалів, Ю. „Прокляті роки Юрія Клена”. Юрій Клен (Освальд Бургардт). Вибране. Київ: Дніпро, 1991 [Kovaliv, Jurij. „Prokliati roky Jurija Klena”. Jurij Klen (Osvald Burghardt). Vybrane. Kyjiv: Dnipro, 1991].

Косач-Кривинюк, О. Леся Українка. Хронологія життя і творчості. Луцьк: Волинська обласна друкарня, 2006 [Kosač-Kryvyniuk, O. Lesia Ukrainka. Chronologija žyttia i tworczosti. Luc'k: Volyns'ka oblasna drukarnia, 2006].

Лексикон загального та порівняльного літературознавства. Чернівці: Золоті литаври, 2001 [Leksykon zahalnoho ta porivnialnoho literaturoznavstwa. Černiwci: Zoloti lytawry, 2001].

Моклиця, М. Модернізм як структура. Філософія. Психологія. Поетика. Луцьк: Вид-во ВДУ імені Лесі Українки, 2002 [Moklycia, M. Modernizm jak struktura. Filosofija. Psycholohija. Poetyka. Luc'k: Vydavnyctvo VNU imeni Lesi Ukrajinky, 2002].

Моклиця, М. Естетика Лесі Українки (контекст європейського модернізму). Луцьк: ВНУ ім. Лесі Українки, 2011 [Moklycia, M. Estetyka Lesi Ukrainki (контекст європейського модернізму). Luc'k: Vydavnyctvo VNU imeni Lesi Ukrajinky, 2011].

Наєнко, М. „Сергій Єфремов і його історико-літературна концепція”. С. Єфремов. Історія українського письменства. Київ: Femina, 1995. 3-15 [Najenko, M. „Serhij Jefremov i joho historyko-literaturna koncepcija”. S. Jefremov. Istorija ukrajins'koho pys'menstwa. Kyjiv: Femina, 1995. 3-15].

Павличко, С. Дискурс модернізму в українській літературі. Київ: Либідь, 1999 [Pawłyczko, S. Dyskurs modernizmu w ukrajins'kij literaturi. Kyjiv: Lybid', 1999].

Поліщук, Я. Міфологічний горизонт українського модернізму. Івано-Франківськ: Лілея-НВ, 2002 [Poliščuk, J. Mifolohičnyj horyzont ukrajins'koho modernizmu. Ivano-Frankivs'k: LilejaNW, 2002].

Рильський, М. Зібрання творів у двадцяти томах. Т. 12. Київ: Наукова думка, 1986 [Ryls'kyj, M. Zibrann'ia tworiv u dwadciaty tomach. T. 12. Kyjiv: Naukova dumka, 1986].

Рыльський, М. Искусство перевода. Статьи, заметки, письма. Москва, 1986 [Ryl's'kyy, M. Yskusstvo perevoda. Stat'y, zametky, pys'ma. Moskva, 1986].

Сірик, Л. Прагнення Європи. Творчість київських неокласиків. Lublin: Wydawnictwo Uniwersytetu Marii Curie-Skłodowskiej 2013 [Siryk, L. Prahnennia Jewropy. Tvorčist’ kyjivśkych neoklasykiv. Lublin: Wydawnictwo Uniwersytetu Marii Curie-Skłodowskiej 2013].

Украинка, Леся, „Заметки о новейшей польской литературе”. Твори в десяти томах. Т. 8. Київ: Дніпро, 1965. 106-133 [Ukrajinka, Lesia. „Zamietki o nowejszej polskoj litieraturie". Twory w desiaty tomach. Т. 8. Kyjiv: Dnipro, 1965. 106-133].

Українка, Леся: „Замітки 3 приводу статті «Політика і етика»”. Твори в десяти томах. Т. 8. Київ: Дніпро, 1965. 234-248 [Ukrajinka, Lesia. „Zamitky z prywodu statti «Polityka i etyka»". Twory w desiaty tomach. T. 8. Kyjiv: Dnipro, 1965. 234-248].

Филипович, П. Літературно-критичні статті. Київ: Дніпро, 1991 [Fylypovycz, P. Literaturno-krytyčni statti. Kyjiv: Dnipro, 1991]. 
Wilczyński, Włodzimierz. Leksykon kultury ukraińskiej. Kraków: Universitas, 2004.

http://www.ukrcenter.com/!FilesRepository/Literature\ [від: 21.11.2017].

PROBLEM IDENTYFIKACJI
TWÓRCZOŚCI ŁESI UKRAINKI

Streszczenie

W artykule podjęto istniejący w literaturoznawstwie problem identyfikacji twórczości Łesi Ukrainki (1871-1913). W literaturoznawstwie ukraińskim pod wpływem teorii narodników historycznie została ukształtowana tradycja zaliczająca pisarkę do neoromantyzmu. Wbrew temu poglądowi w proponowanym badaniu wysunięto tezę o przynależności pisarki do klasycystycznego typu twórczości, mianowicie do neoklasycyzmu jako jednego z kierunków modernizmu europejskiego. Swoje twierdzenia autor argumentuje na podstawie poglądów pisarki dotyczących samoidentyfikacji, a także materiałów historyczno-literackich i prac krytycznoliterackich neoklasyków ukraińskich pierwszej fali, którzy rozwinęli swoją działalność w latach 20. XX wieku. Wyniki badań świadczą o zdecydowanym zaprzeczeniu przez Łesię Ukrainkę opinii o niej, którą sformułował czołowy przedstawiciel narodnickiej koncepcji S. Jefremow. Pisarka uważała ją za tendencyjną i nieadekwatną. Pokazano, że w latach 1914-1930 neoklasycy kijowscy: M. Draj-Chmara, M. Zerow, P. Fyłypowycz, M. Rylski i Jurij Kłen argumentowali europeizm pisarki i realizację przez nią artystyczno-światopoglądowych zasad neoklasycyzmu, mianowicie: zwrócenie się do antyku, wykorzystanie i reinterpretacja „wiecznych obrazów" i istniejących fabuł tradycji śródziemnomorskiej, synteza wartości uniwersalnych i narodowych, indywidualny wybór i twórczy mimesis, synkretyzm kulturowy i stylowy, antropocentryzm, dystans do szarej codzienności, moralizatorstwo, aktywność obywatelska. Artykuł stanowi próbę zaakcentowania konieczności weryfikacji istniejących opinii oraz identyfikacji twórczości według kryterium estetycznego.

Słowa kluczowe: literatura ukraińska; Łesia Ukrainka; kierunek artystyczny; neoromantyzm; neoklasycyzm; identyfikacja twórczości.

\section{LESIA UKRAINKA'S LITERARY WORKS PROBLEM OF INDENTIFICATION}

\section{S u m m ary}

The article raised the issue of identification of Lesya Ukrainka's literary heritage (18711913). Ukrainian literary science being under the influence of Narodnik (populist) tradition historically treated her as a representative of neo-romanticism. Contrary to this point of view this study puts forward the thesis that the writer belongs to the classicism, namely to the neoclassicism as a form of European modernism. This statement is based on the expressed by the 
playwright point of view as to the self-identification, as well as historical and literary materials, and literary criticism works of Ukrainian neoclassics of the so called first wave, which have developed their activity in the 20 -th years of the 20 -th century. Results of the study indicate a emphatic denial by the poet of her characteristics as had been formulated by the leading representative of the Narodnik S. Yefremov. The writer considered it biased and inadequate. It was found out that the kiev neoclassic-in the years 1914-1930 M. Dray-Khmara, M. Zerov, P. Fylypovych, M. Rylsky and Yurii Klen backed up the statement that Lesya Ukrainka belonged to Europian literary tradition which is supported by her implementation of artistic and philosophical neoclassicism devices such as appeal to antiquity, the use and reinterpretation of „eternal images” and „traveling stories”, mediterranean tradition, individual choice and creative mimesis, cultural and stylistic syncretism, synthesis of universal with national, anthropocentrism, distancing from the trivial, moralizing, social activity. The article is an attempt to emphasize the need to review existing opinions and of identification creativity according to the aesthetic criterion.

Key words: Ukrainian literature; Lesya Ukrainka; literary; artistic direction; neo-romanticism; neoclassicism; identification of literary heritage. 